\title{
Nanofluids in Cooling Systems and Their Efficiency
}

\author{
D.A. Volchenko ${ }^{1}$, M.V. Kindrachuk ${ }^{2}$, B.V. Dolishniy ${ }^{1}$, V.S. Skrypnyk ${ }^{1}$, D.I. Zhuravlov ${ }^{1}$, l.B. Malyk ${ }^{3}$, \\ A.O. Yurchuk ${ }^{2}$, A.O. Dukhota ${ }^{2}$ \\ ${ }^{1}$ Ivano-Frankivsk National Technical University of Oil and Gas, 15, Karpatska St., 76000 Ivano-Frankivsk, \\ Ukraine \\ ${ }^{2}$ National Aviation University, 1, Liubomyra Guzara Ave, 02000 Kyiv, Ukraine \\ ${ }^{3}$ Drohobych Specialized College of Oil and Gas, 57, M. Hrushevskyi St., 82100 Drohobych, Ukraine
}

(Received 10 March 2021; revised manuscript received 09 August 2021; published online 20 August 2021)

\begin{abstract}
In the materials of the article, it is shown that based on multifactor analysis, the proposed models of nanofluids are taken into account in the base fluids; a collision between nanoparticles and molecules; nanoparticles that occur due to Brownian motion; thermal diffusion of nanoparticles and their interaction with molecules; formation of percolation trajectories with low heat capacity in a fluid; influence of interphase and boundary layers in the separation of the solid and fluid phases; the surface shell effect; thin nanolayers; particle clustering. The study of nanofluids comes down to determining their thermal conductivity coefficient. It is established that the obtained values of thermal conductivity coefficients, which are 10 times higher than usual, do not fit into the classical calculation schemes used to determine the heat transfer coefficients. For cavities of nanofluid cooling systems, the thermal resistances of heat transfer and thermal conductivity are fictitious in magnitude. This is due to the fact that in the cooling cavities, the driving force is the potential jumps between the layers of the nanofluid. We selected the materials for creating nanoliquids that will be used in the new design of the braking system. It is formed by $\mathrm{Al}_{2} \mathrm{O}_{3}$ particles enveloped by polymeric material FK-24A. The diameter of nanoparticles was 15,35 and $80 \mu \mathrm{m}$. An increase in particle size and concentration results in an increase in the thermal conductivity of the liquid. In place of nanoliquid and metal components contact, the electrical potential and intensity of the electric field of nanoliquid change, that is also described here. When the temperature of the nanofluid rises above $100{ }^{\circ} \mathrm{C}$ it may become an electrolyte. The use of nanofluids in lubrication of drawworks braking system reduces the wear of friction couples by $\sim 20 \%$ and increases the braking moment by about $13 \%$.
\end{abstract}

Keywords: Internal combustion engine, Braking device, Nanofluid, Nanoparticles in a polymer shell, Potentials: thermal, electrical and chemical.

DOI: 10.21272/jnep.13(4).04013

PACS numbers: 81.15. - z, 61.43.Gt, 52.40.Hf

\section{INTRODUCTION}

Suspensions based on solid-phase nanoparticles are called nanofluids [1]. The thermal conductivity of suspensions with a low concentration of solid-phase particles can be described by Maxwell's theory [2]. The theory is based on a number of assumptions: the concentration of solid-phase particles is small (the distance between the particles significantly exceeds their size); particles are immobile in a fluid; particles are spherical; the equations of conductive heat transfer are valid to describe the process of heat transfer. When using particles of nanometer range wrapped in a polymer film which are dipoles, when a nanofluid moves in cooling systems, a transformation of charges occurs, leading to the formation of electronic and ionic zones. The driving forces in nanofluids are jumps of various kinds of potentials.

Nanofluids in cooling systems for motors, brakes, heating, and ventilation can significantly increase the heat transfer coefficient.

It is hard to imagine nanofluid's successful usage as cooling liquids without detailed knowledge of their thermal, physical, and other properties. For this purpose, we analyzed papers related to the study of nanofluids.

In papers [1-3], the thermal conductivity of ultrafine oxide suspensions of aluminum, silicon, and titanium in water at a volume concentration of the order of several percent exceeds the thermal conductivity of a pure fluid by tens of percent.
The experimental results with nanoparticles of various sizes indicate that the thermal conductivity of a fluid based on larger particles may be described using Maxwell's theory [2].

First of all, the data obtained correlate with theoretical models constructed to describe coarsely dispersed suspensions' thermal conductivity. The first such model was created by Maxwell [2], who determined the relation between the coefficient of thermal conductivity of the suspension $\lambda$ and the base fluid $\lambda_{0}$.

Analysis of nanoparticles size effect on the thermal conductivity coefficient $(\alpha)$ of nanofluids shows that the nanofluid coefficient $\lambda$ increases with increasing nanoparticle size [4].

In [5], the modeling of the nanofluid thermal conductivity coefficient is presented as a function of different nanoparticle mass. The authors established that $\lambda$ of nanofluids at fixed sizes and nanoparticle concentrations increases with an increase in their mass. The dependence of the increase in the thermal conductivity of nanofluids on the nanoparticles mass means, at the same time, the same dependence on the particles density at the same size.

The nanofluid thermal conductivity coefficient also depends on the nanoparticles' shape (spherical, cylindrical, prismatic, flat, or elliptical). In [2, 3], thermal conductivity of nanofluids with $\mathrm{ZnO}$ nanoparticles having prismatic and spherical shapes was experimentally investigated at various volume concentrations of nano- 
particles in the range from 0.05 to $5.0 \%$. The $\lambda$ coefficient of nanofluids with zinc oxide nanoparticles increased by 12 and $18 \%$, respectively, for spherical and prismatic nanoparticles at $\varphi=5.0 \%$ compared to the $\lambda$ coefficient of the base fluid - water.

However, many experimental data obtained by now have a wide dispersion and often contradict each other. Some of the data indicate an abnormal increase in the nanofluids thermal conductivity compared to the theory [1]. However, in joint studies carried out by different foreign organizations, no abnormal increase in thermal conductivity at low nanoparticle concentrations was found [6].

The classification of nanofluids and the analysis of theoretical approaches to modeling the transfer coefficients were carried out in [7]. In particular, they note that a rigorous theory of transfer processes in nanofluids has not yet been developed. The use of molecular dynamics modeling of thermal conductivity still gives predictions different from the classical approach.

The large dispersion of experimental data is associated with many objective reasons: the method of nanoparticle synthesis, the nanoparticle size distribution function, the nanofluid preparation technology, the method for measuring thermal conductivity and interpreting the results.

Devices and systems for forced air and fluid cooling of braking devices' friction couples are known [8-11]. However, they have an efficiency of no more than $10 \%$. Combined cooling (air-nanofluid) for braking devices with a heavy metal friction element is promising.

Substantially heterogeneous designs of disc brakes operating under intense thermal-force loading conditions require the development of mathematical models and methods for calculating heat transfer and stress state. In [12-15], the authors studied heat conductivity and layered structures' mechanics, including lowdimensional layers and proposed analytical research methods. Analytical, numerical and experimental studies of energy dissipation due to friction in layered shell and bar structures are presented in [16-20]. Temperature effects during the interaction of elastic bodies under conditions of frictional contact and local heating are taken into account, in particular, by the authors of publications [21-25].

High-quality hardening of discs working surfaces and the thermal barrier effect are provided by oxide coatings formed in the micro-arc oxidation of compacted aluminum and titanium alloys [26-30] or the upper part of the aluminum layer previously deposited on steel [31,32]. Composite coatings may also increase wear resistance [33-39]. Other types of coatings [40, 41] are not always practical.

Problem statement. It is necessary to solve the problem of using nanofluids in motors and braking devices cooling systems and evaluate the efficiency of reducing its energy load.

The article's central questions are general information; interaction of nanoparticles in fluid cooling systems; the nanofluid efficiency in cooling the beltshoe brake's compound pulley.

The work objective is to select nanoparticles for nanofluids and check their effectiveness on a developed new type of brake pulley.

\section{STATE OF THE ART AND PROBLEM STATEMENT}

General information. In fluid cooling systems of many internal combustion engines, low-freezing fluids are mainly used; those fluids are mixtures of ethylene glycol with water in proportions related to the solution's required freezing point. Aqueous fluids of ethylene glycol meet the requirements of GOST 28084-84 for the characteristics of coolants for engines and brakes fluid cooling systems, which must have:

- optimal viscosity at which, on the one hand, losses through all kinds of seals and connecting assemblies are reduced and, on the other hand, significant energy consumption for the coolant passage in cooling circuits of motors and brakes is not required;

- a freezing point which will be lower than the ambient temperature that will facilitate engine start and ensure operation in operating conditions;

- a boiling point that will be higher than $25 \ldots 30{ }^{\circ} \mathrm{C}$ of the maximum allowable temperature of the coolant in the engine cooling system, which will prevent the appearance of steam-air plugs in it and reduce its losses during evaporation;

- a high value of heating capacity that will reduce the coolant volume, helping to maintain the required temperature mode of engines and brake friction couples.

According to a linear law, during experimental studies on the cooling systems of internal combustion engines and braking devices, an increase in nanofluids temperature is observed, which contributes to the rise of their thermal conductivity coefficient.

Friction materials based on thermoactive resins that act as shells for nanoparticles must contain components that promote dipoles formation. Such components guarantee an increase in durability: resin particles and graphite; thermal conductivity: copper, brass, bronze, aluminum (in the form of powder, shavings, or wire); a reduction in consumption and scuffing on the surface of nanoparticles: lead. In this case, it is necessary to keep the dependence of the trapped dipoles mobility on the thermal and electric fields.

Nanofluids should be stable from the performance point of view, resistant to solid nanoparticles' agglomeration and precipitation during the lifespan. It is worth mentioning that there should be no chemical reactions in nanofluids. When using nanofluids as a coolant for cooling systems of internal combustion engines and braking devices, they should not cause corrosion of the structure.

As a material for nanoparticles, we selected aluminum oxide $\mathrm{Al}_{2} \mathrm{O}_{3}$, wrapped in a polymer shell made of FK-24A material.

The presence of a polymer film on nanoparticles leads to decreased resistance in the "metal-polymer" system, which is more expressed as the polymer film's thickness increases. At a thickness $>60 \mathrm{~nm}$ calculated coulometrically the resistance no longer depends on the film thickness and nanofluid composition. However, a thinner polymer layer does not entirely prevent nanofluid contact with the surface. Measurements show this in solutions containing benzenesulfonate, ferri-ferrocyanide ions, quinone-hydroquinone, or cations ( $\mathrm{Sn}^{2+}$ ions), which can be 
subjected to changes. The resistances are different in the reduced (amine) and oxidized (imine) polymer states. Imine groups probably scatter conduction electrons more diffusely than amine ones, and therefore the resistance is higher in the oxidized state. During the transition from one state to another, the resistance changes from the value corresponding to the polymer film's completely oxidized state. The effect of polymer degradation occurs when the permissible anode potential values are reached, expressed in the resistance increase. Degradation leads to a distance increase between the scattering centers and more diffuse scattering. The change in resistance occurs almost linearly with an increase in the oxidation state of the polymer. We assume that this is how the specularity parameter changes with a change in the oxidation state. These found effects allow us to conclude that the surface conductivity method for changing the nanofluid properties, which becomes an electrolyte [42, 43], leads to an increase in its thermal conductivity coefficient.

Semiconductors with intrinsic and polymer conductivity of $n$ - and $p$-type, for which surface effects play a significant role, belong to a special class system. Investigation of the semiconductor nanoparticle's surface properties is beyond the scope of this article.

\section{INTERACTION OF NANOPARTICLES IN FLUID COOLING SYSTEMS}

Let us turn our attention to a number of physical phenomena. If all these phenomena are caused by electric current then this points to galvanomagnetic effects. If those physical phenomena occur due to the heat flux, they are called thermomagnetic effects. Further, these effects can be divided into transverse effects where the primary current and the resulting effect are in the same direction. Besides, we can talk about the isothermal effect, when the temperature gradient is zero in the direction perpendicular to the primary current, and the adiabatic effect, when the heat flux perpendicular to the primary current is zero.

Longitudinal and transverse effects in nanofluids intensify their movement in cooling systems cavities. The driving force for nanofluids is potential jumps due to the transformation of charges according to the "flat volumetric" and "volumetric - flat" scheme.

Let us consider the charge-discharge properties of two- and three-layer structures of nanofluids located in cooling systems cavities (Fig. 1).

The processes of internal charge relaxation in nanofluids are controlled by the effect of thermal conductivity. Such characteristics determine it as carriers mobility, their charges concentration in nanofluids layers etc., in substances capable of holding a charge for a long time, which have centers to capture the carriers; therefore, the mobilities of the latter are suppressed by capture processes. Capture has a similar effect on conductivity. In addition to intrinsic charge carriers, the nano-fluid may also contain impurity carriers injected inside through the boundaries of nanofluid layers (Fig. 2).

The material ability to keep various states - free (delocalized) - has a different effect on carrier mobility. The electron or ion motion with energy near the lower edge of the conduction band is quantum mechanical tunneling between delocalized states lying on the energy scale above the mobility edge. This process does not require any thermal activation and the corresponding mobility turns out to be relatively high, about $10 \mathrm{~cm}^{2} /(\mathrm{V} \cdot \mathrm{s})$. For the movement of electrons captured by a superficial level located in energy below the mobility edge, a certain thermal energy is required obtained from the brake's friction couple or from a running engine. Such electrons' motion process is thermally activated and comes down to the next hops between localized states contributing to various kinds of potentials.

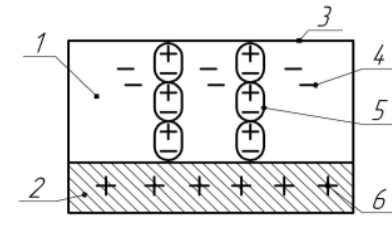

a

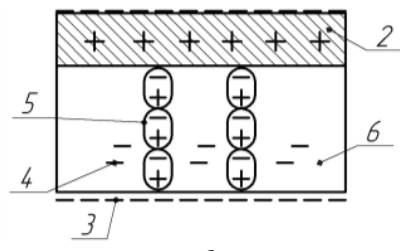

$\mathrm{b}$

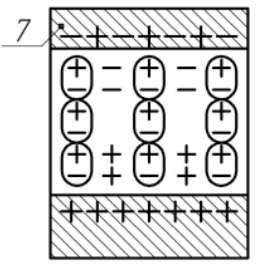

$\mathrm{c}$

Fig. 1 - Schematic section of two- (a) and three-layer (b, c) structures of nanofluid layers: 1 - nanofluid; 2, 7 - cavity walls; 3, 4, 5, 6 - surface charges, bulk, dipole (or displaced), compensation

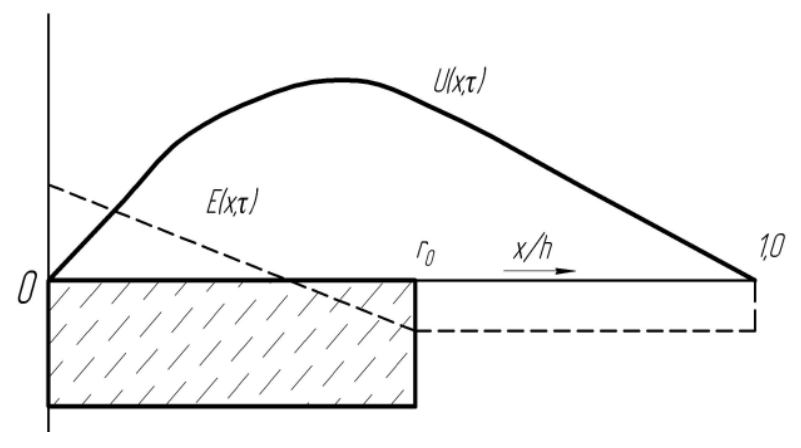

a

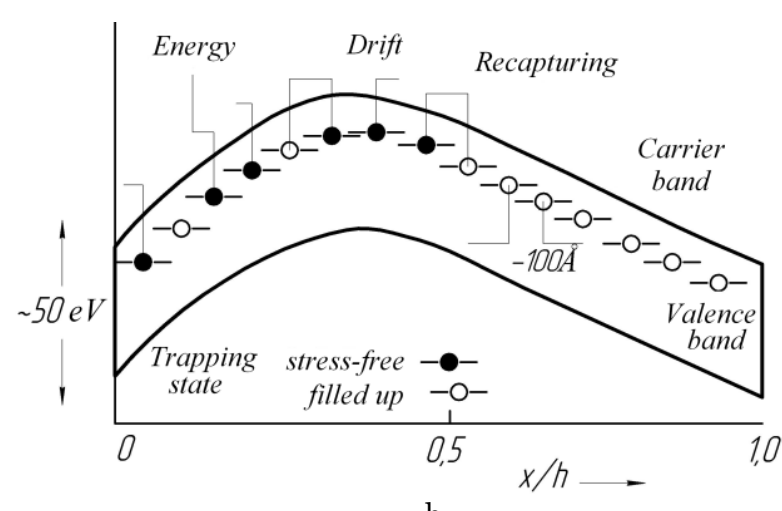

$\mathrm{b}$

Fig. 2 - Regularities of changes in the potential $[U(x, \tau)]$ and strength $[E(x, \tau)]$ of the electric field (a) and energy bands of nanofluid layers (b) when interacting with the metal walls of the cavities, depending on the parameter $x / h: x$-coordinate; $h$ - thickness of the surface layer of the nanofluid; $r_{0}$ - media capture depth 
The corresponding mobility is several orders of magnitude smaller than in the first case [about $103 \mathrm{~cm}^{2} /(\mathrm{V} \cdot \mathrm{s})$ ]. Finally, the carrier capture time at a deep level is very long. If the majority of electrons are captured by a deep conductivity level, such capture becomes extremely small $\left[10^{-10}-10^{-17} \mathrm{~cm}^{2} /(\mathrm{V} \cdot \mathrm{s})\right]$. In many nanofluids without their own carriers, they can be created by injection from nanoparticle layers. If the inflow of carriers due to injection exceeds the particle flux transported through the bulk of the nanofluid layers, then the currents are limited by the field of the generated space charge. In the opposite case, the currents are determined by the intensity of injection from the nanofluid.

The presence of strong fields changes currents magnitude in the mode of their limitation by the space charge field. In this case, the field gradient lowers the trapped carriers' energy barriers even when the traps are neutral in the unoccupied state.

A discussion of charge relaxation would be incomplete without at least a few remarks about the transverse propagation of surface and space charges. Generally speaking, the field in nanofluids is directed perpendicularly to surfaces with very small components along with them. Thus, the field does not contribute to charge propagation processes in transverse directions.

Suppose that the temperature dependence of the free carriers' mobility is less (usually $T^{-1}$ or $T^{-2}$ ) than the mobility of trapped carriers. In this case, it is already exponential since the motion process of such carriers has a thermally activated character.

The transfer time measurements during time intervals from $\mu$ s to $\mathrm{ms}$ give significantly lower values for mobility - approximately $10^{-6}-10^{-7} \mathrm{~cm}^{2} /(\mathrm{V} \cdot \mathrm{s})$. One is inclined to think that such a decrease is associated with the loss of carriers due to their capture by shallow levels. Finally, the results of charge relaxation experiments in this material for times from minutes and more give "stationary" mobility with values of the order of $10^{-14} \mathrm{~cm}^{2} /(\mathrm{V} \cdot \mathrm{s})$ determined by the time of carrier capture by deep levels.

Nanofluid particles were studied in laboratory settings (Fig. 3). In all cases, the relative coefficient of thermal conductivity $\left(\lambda_{1} / \lambda\right)$ was increased. Only in the case (Fig. 3c) for particle sizes of 15 and $35 \mathrm{~nm}$ (lines 1 and 2, respectively), no significant difference in coefficient values was observed.

In large volumes of nanofluids in composite pulley's cavities, these regularities will be completely different.

Calculations of the chemical and electrochemical potentials of electrons and ions of nanofluids were carried out using dependences (1)-(3).

An estimate of the chemical potential change of electrons $\varphi$ depending on the nanofluid temperature $T$ [44] is found from the expression

$$
\Delta \phi_{t}=\left(\pi K_{\delta}\right)^{2}\left(T^{2}-T_{0}^{2}\right) /\left(4 q_{e} E_{F}\right),
$$

here $K_{\delta}=1.38 \cdot 10^{-23} \mathrm{~J} / \mathrm{K}$ is the Boltzmann constant, $T$ $T_{0}$ is the temperature difference, $\mathrm{K} ; q_{e}=1.6 \cdot 10^{-19} \mathrm{Kl}$ is the electron charge; $E_{F}$ is the Fermi energy, eV.

In turn, the electrochemical potential of the $k^{\text {th }}$ type ion is:

$$
\bar{\mu}_{k}=\mu_{k}+z_{k} E_{F}=\mu_{k}^{0}+R T \ln \alpha_{k}+z_{k} E_{F}+\mu_{a},
$$

here $\mu_{k}^{0}, \mu_{k}$ - initial and final potential value, $z_{k}-$ ion charge; $q_{u}=1,6 \cdot 10^{-19} \mathrm{Kl} ; E_{\mathrm{F}}-$ Fermi energy, eV; $R-$ gas constant, $R=8.314 \mathrm{~J} \cdot \mathrm{mol}^{-1} \cdot \mathrm{K}^{-1}, \mu_{a}-$ molecular weight; number $\alpha_{k}$ - activity.

The expression determined the character of local heat transfer coefficient distribution along the surface of the inner polished part of composite pulley rim (Fig. 4):

$$
N u_{1}=\frac{\alpha(x) x_{0}}{\lambda}=C_{1} x^{0.5}, \alpha(x)=C_{2} x^{0.5},
$$

where $C_{1}$ and $C_{2}$ are calculated from the terms of solutions unambiguity.

Consequently, along the surface of the pulley rim, the thickness of the boundary layer $\delta T(x) \sim x^{0.5}$ increases $[43,44]$

$$
\frac{\delta_{T}}{x}=\frac{5}{\operatorname{Re}_{x}^{0.5} \cdot \operatorname{Pr}^{0.33}}
$$

Re and Pr are, respectively, the Reynolds number and the Prandtl criteria.

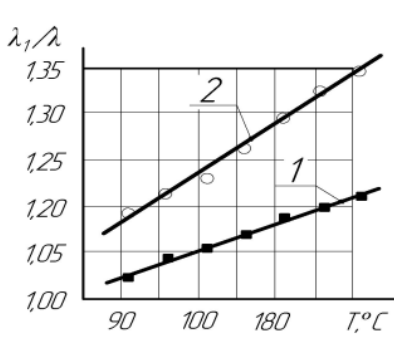

a

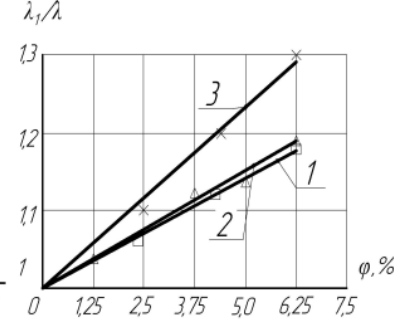

$\mathrm{b}$

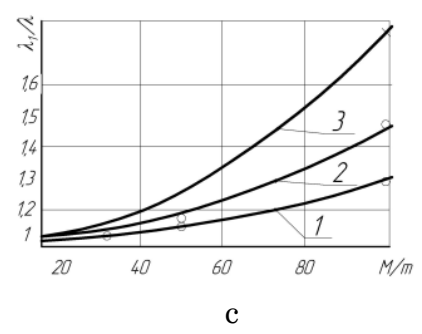

Fig. 3-Regularities of changes in the relative coefficient of nanofluids thermal conductivity with particles of aluminum oxide $\mathrm{Al}_{2} \mathrm{O}_{3}$ wrapped in a polymer shell made of $\mathrm{FK}-24 \mathrm{~A}$ material, depending on (a) - temperature: $1-\varphi=1 \% ; 2-\varphi=4 \%$; (b) - concentration of $\mathrm{Al}_{2} \mathrm{O}_{3}$ particles at their various sizes: 1 $15 \mathrm{~nm} ; 2-35 \mathrm{~nm} ; 3-80 \mathrm{~nm}$; (c) - masses of nanoparticles at different volumetric concentrations: $\circ-\varphi=0.12 \%$; $\diamond-\varphi=0.24 \%(+)-\varphi=0.48 \%$; and $m$ is the mass of nanoparticles and molecules

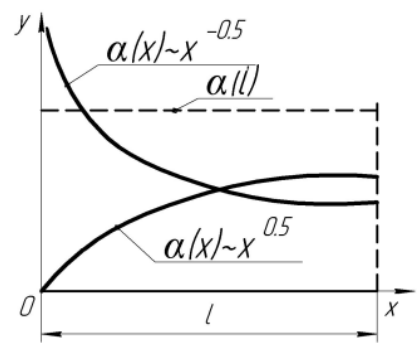

Fig. 4 - Dependence of the local heat transfer coefficient $(\alpha)$ of the pulley rim polished surface on the thickness $(\delta)$ of the nanofluid boundary layer 
In this case, the local value of the heat transfer coefficient $\alpha(x) \sim x^{0.5}$ decreases proportionally (Fig. 4).

Let us proceed with assessing the nanofluid cooling efficiency of a composite belt-shoe brake pulley.

\section{NANOFLUID EFFICIENCY IN COOLING A COMPOSITE BELT-SHOE BRAKE PULLEY}

To optimize the friction belt-shoe brake's unit elements, a nonlinear programming instrument is used, which is implemented in the optimization module. The meaning of the latter is to find such values of design parameters (brake pulley and belt, as well as friction lining), at which a certain value called the objective function takes an extreme (maximum or minimum) value. Simultaneously, several operational and design parameters of brake frictional units in this range or in func- tional dependences must satisfy the constraints in the form of equalities/inequalities. The optimization algorithm implemented in Ansys Workbench has versatility sufficient for solving typical tasks, but at the same time, it contains a number of features that must be considered. The block diagram of the algorithm is in Fig. 5 .

With an increase in mass, in which heat is distributed, the brake pulley rim's heat transfer surface also increases due to the heat dissipation surface of its sidewalls. Therefore, the choice of the friction unit design is made depending on the requirements for its dimensions, energy load of the surface and near-surface layers of friction couples, permissible specific load on the contact, contact stiffness of the friction couple elements, developed braking torque and allowable surface temperature for the active layers of the polymer lining.

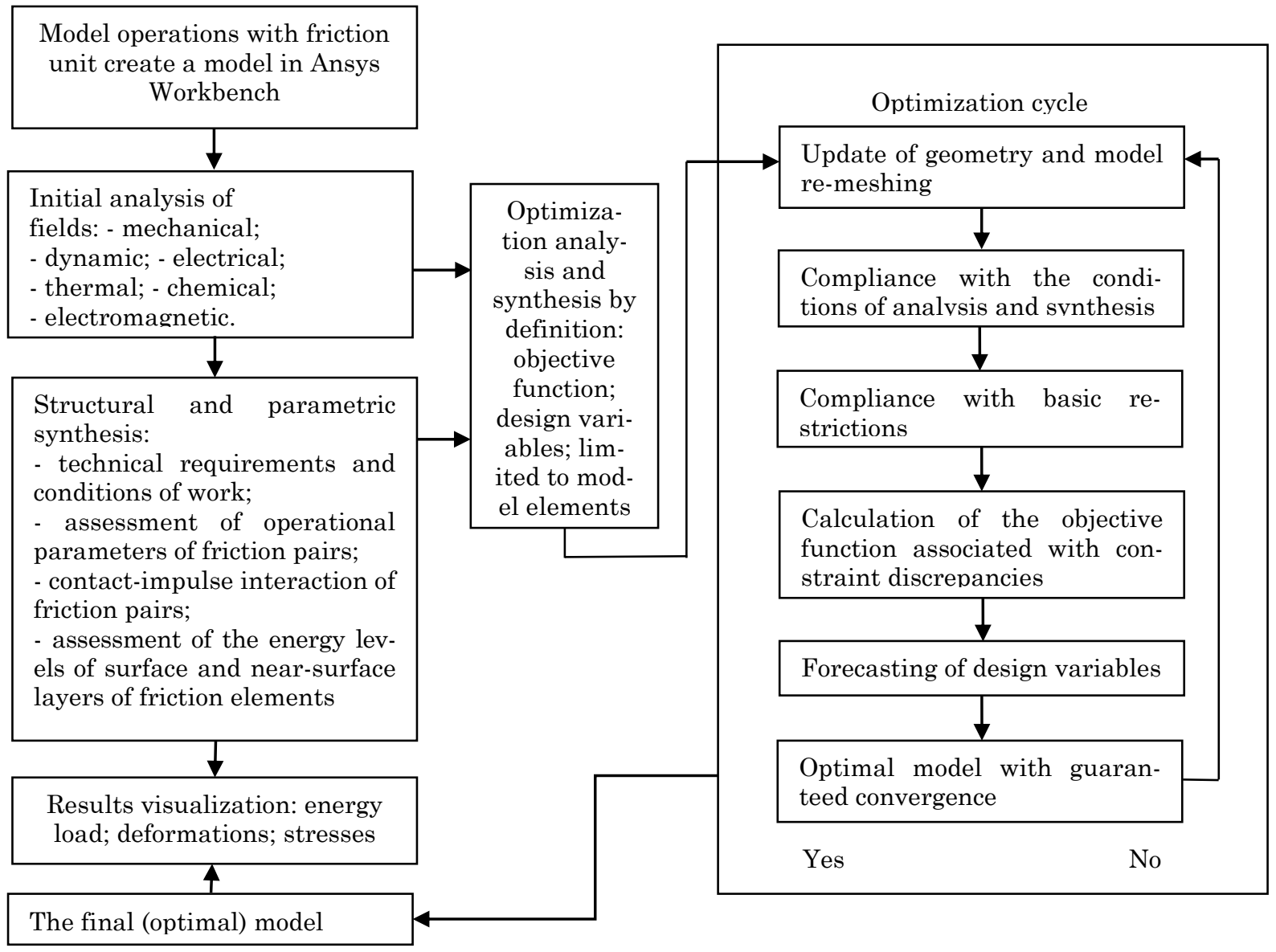

Fig. 15 - Block diagram of the optimization algorithm for the design parameters of the friction unit

During designing a composite brake pulley, the following restrictions were set:

- the temperature of the composite brake pulley friction surface is $390^{\circ} \mathrm{C}$;

- the polished area of the pulley rim lower part should be $2 / 3$ area of the friction surface upper part;

- the inner surface (matte) of the annular chambers and the holes between them should be $20-25 \%$ of the outer brake pulley flat finish. The air-cooling efficiency should be the same due to the amount of air entering the brake pulley;

- the thickness of the upper pulley part: 16.0-
$18.0 \mathrm{~mm}$; lower part: $8.0-10.0 \mathrm{~mm}$; the volume of the chamber with the fluid must ensure the heat removal of at least $30 \%$ at a temperature of $390{ }^{\circ} \mathrm{C}$;

- the temperature gradient for the pulley upper part: up to $25.0^{\circ} \mathrm{C} / \mathrm{mm}$; in the partition of the chambers: up to $10.0^{\circ} \mathrm{C} / \mathrm{mm}$; through the chamber wall: up to $50.0^{\circ} \mathrm{C} / \mathrm{mm}$.

Having regard to the above, Fig. 6 shows a drawing of the designed brake pulley with a nanofluid chamber. The chamber is designed without inlet and outlet valves. 


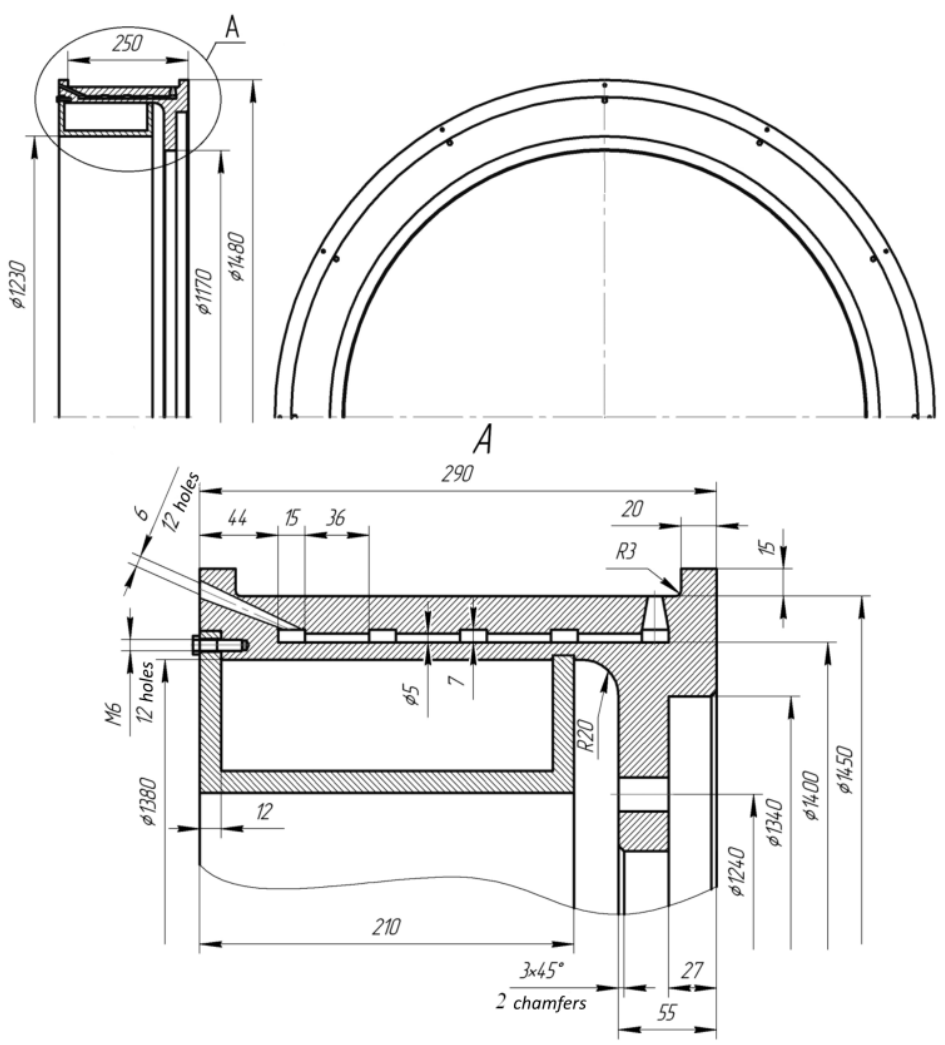

Fig. 6 - Designed composition of the drawworks brake pulley with a nanofluid chamber

Table 1 shows the leading design and operational parameters of serial and improved friction couples (with nanofluid cooling) of belt-shoe brakes.

The system analysis of the energy load at constant specific loads in friction couples of the serial and improved belt-shoe brakes made it possible to state the following:

- the developed design of a composite brake pulley with a forced air-nanofluid cooling system is highly efficient (the dynamic coefficient of friction and the braking torque increased by $13.1 \%$ ) due to the opera- tion of friction-pad materials at surface temperatures below permissible, i.e., $390^{\circ} \mathrm{C}$, but at the same time, there was an increase in the weight and moment of inertia of the composite brake pulley, respectively, by $24.7 \%$ and $21.7 \%$ compared to the serial brake pulley;

- at the same operating surface temperature of the compared pulleys, the volumetric temperatures in the upper and lower parts of the composite pulley are $21.8 \%$ lower than that of the serial pulley, but in the first design, large volumetric temperature gradients were observed by $24.5 \%$ than in the serial pulley;

Table 1 - The main operational parameters of serial and advanced friction couples of belt-shoe brakes

\begin{tabular}{|c|c|c|c|}
\hline \multirow{2}{*}{ № } & \multirow{2}{*}{ Operating factors } & \multicolumn{2}{|c|}{ Friction couples of belt-shoe brakes } \\
\hline & & original & improved \\
\hline \multirow[t]{3}{*}{1.} & $\begin{array}{l}\text { Brake pulley weight, } \mathrm{kN} \text { : } \\
\text { without camera }\end{array}$ & 4.744 & 4.508 \\
\hline & with the camera without nanofluid & - & 5.849 \\
\hline & with camera and nanofluid & - & 6.303 \\
\hline \multirow[t]{3}{*}{2.} & $\begin{array}{l}\text { Inertia moment of the brake pulley, } \mathrm{kg} \cdot \mathrm{m}^{2} \text { : } \\
\text { without camera }\end{array}$ & 233.85 & 221.89 \\
\hline & with camera without nanofluid & - & 278.48 \\
\hline & with camera and nanofluid & - & 298.58 \\
\hline \multirow[t]{3}{*}{3.} & Dynamic coefficient of friction, $f$ & 0.33 & 0.38 \\
\hline & stability, $\alpha_{\mathrm{st}}=f_{\mathrm{av}} / f_{\max }$ & 0.90 & 0.926 \\
\hline & fluctuation, $\alpha_{\mathrm{f}}=f_{\min } / f_{\max }$ & 0.79 & 0.83 \\
\hline \multirow[t]{2}{*}{4.} & $\begin{array}{l}\text { Braking: } \\
\text { efficiency, } \beta_{\mathrm{eff}}=\alpha_{\mathrm{st}} / \tau^{2}, 1 / \mathrm{s}^{2}\end{array}$ & 0.00625 & 0.00643 \\
\hline & $\begin{array}{l}\text { Reduced efficiency } \\
H_{\mathrm{b} . \text { eff. }}=\alpha_{\mathrm{st}} /\left(\tau^{2} \cdot \Delta g\right), 1 /\left(\mathrm{s}^{2} \cdot \mathrm{g}\right)\end{array}$ & $1.036 \cdot 10^{-2}$ & $1.227 \cdot 10^{-2}$ \\
\hline 5. & Unit loading, $p, \mathrm{MPa}$ & 1.2 & 1.2 \\
\hline 6. & Braking torque, Mbr, $\mathrm{kNm}$ & 174.3 & 200.7 \\
\hline
\end{tabular}




\begin{tabular}{|c|c|c|c|c|}
\hline \multirow{2}{*}{ № } & \multirow{2}{*}{ Operating factors } & \multicolumn{3}{|c|}{ Friction couples of belt-shoe brakes } \\
\hline & & original & & oved \\
\hline \multirow[t]{3}{*}{7.} & \multirow{3}{*}{$\begin{array}{l}\text { Temperatures and their gradients, } \\
{ }^{\circ} \mathrm{C} /\left({ }^{\circ} \mathrm{C} / \mathrm{mm}\right)\end{array}$} & \multirow{3}{*}{ pulley } & \multicolumn{2}{|c|}{ compound pulley } \\
\hline & & & upper & lower \\
\hline & & & \multicolumn{2}{|c|}{ part } \\
\hline & superficial & $390 / 1.2$ & $390 / 1.8$ & $390 / 1.9$ \\
\hline & voluminous & $358 / 2.4$ & $340 / 4.39$ & $270 / 6.5$ \\
\hline \multirow[t]{3}{*}{8.} & Predicted potentials (eV): & & & \\
\hline & temperature & 0.47 & \multicolumn{2}{|c|}{0.55} \\
\hline & electrochemical & - & \multicolumn{2}{|c|}{0.74} \\
\hline 9. & $\begin{array}{l}\text { Temperature stresses/ their gradients, } \\
\mathrm{MPa}(\mathrm{MPa} / \mathrm{mm})\end{array}$ & $796.85 / 4.61$ & $406.56 / 9.24$ & 189.79/3.04 \\
\hline 10. & Lining wear, $\Delta g, g$ & 60.3 & \multicolumn{2}{|c|}{50.4} \\
\hline
\end{tabular}

- the gradient of temperature stresses from the side of the rim free edge in its upper part is $13.03 \mathrm{MPa} / \mathrm{mm}$, while from the side of the pulley rim clamped edge, it reaches $10.14 \mathrm{MPa} / \mathrm{mm}$; as for the pulley rim lower part here along its length there are temperature stress gradients of 2.51 and $6.59 \mathrm{MPa} / \mathrm{mm}$, respectively; in the first case, this is due to the insufficient efficiency of the matte surfaces forced cooling with an evaporative condensation fluid system washing the polished surface of the rim lower part;

The linings' weight wear is less in improved friction couples by $13.2 \%$ than in serial brake friction couples.

\section{CONCLUSIONS}

A computational-experimental method for determining losses to the environment by the surfaces of composite brake pulleys in industrial conditions with natural and forced cooling by air, as well as by nanoflu$\mathrm{id}$, is illustrated:

- the proposed models for nanofluids are taken into account in base fluids: the collision between nanoparticles and molecules; nanoparticles which are due to Brownian motion; thermal diffusion of nanoparticles; thermal interaction of nanoparticles with molecules;

\section{REFERENCES}

1. V.Ya. Rudyak, A.V. Minakov, M.I. Pryazhnikov, Lett. J. Tech. Phys. 42 No 24, 9 (2017)

2. A.V. Gorshkov, Ensuring the permissible temperature level of forced marine diesel engines by intensifying heat transfer in cooling systems due to the modification of coolants with nanoparticles: cand. tech. sciences thesis: 05.08.06/Gorshkov Roman Vladimirovich. 127 (Russia: Yaroslavl: 2019).

3. V.Ya. Rudyak, Statistical aerohydromechanics of homogeneous and heterogeneous media. Vol. 2. Hydromechanics (Russia, Novosibirsk: NGASU: 2005).

4. E.S. Choi, J.S. Brooks, D.L. Eaton, M.S. Al-Haik, M.Y. Hussiani, H Garmestani, D. Li, K. Dahmen, J. Appl. Phys. 94 No 9 , 6034 (2003).

5. X. Wang, X. Xu, S. Choi, J. Thermophys. Heat Trans. 13 No 4, 474 (1999).

6. J.C. Maxwell, A treatise on electricity and magnetism, 2nd Ed., 1, 435 (Clarendon Press: 1881).

7. J.A. Eastman, S.U.S. Choi, S. Li, L.J. Thompson, S. Lee, Enhanced thermal conductivity through the development of nanofluids, Materials Research Society (Boston: FallMeeting: 1998).

8. V. Marchuk, M. Kindrachuk, A. Kryzhanovskyi, Aviation 18 No 4, 161 (2014).

9. A.Kh. Dzhanakhmedov, D.A. Volchenko, N.A. Volchenko formation of percolation trajectories with low heat capacity in the fluid; influence of the interphase layer at the interface between the solid and fluid phases; surface shell effect; thin nanolayers; particles clustering. It is important to note that such models are applicable for specific nanofluids and, in general, do not allow one to determine their thermal conductivity coefficient accurately;

- a nanoparticle in a polymer shell is simultaneously: a semiconductor element that enhances the electrical conductivity of the nanofluid; a dipole that promotes the appearance of an electric field when nanoparticles are heated in systems cooling cavities; in the latter, the driving force is temperature (up to $100{ }^{\circ} \mathrm{C}$ ) and electrochemical potentials;

- at temperatures above $100{ }^{\circ} \mathrm{C}$ it is observed an increase in the electrochemical potential and the formation of electronic and ionic zones in the system cavity enabling potential jumps; in this case, the nanofluid acts as an electrolyte;

- the use of nanofluid in the cooling system of a composite belt-shoe brake pulley made it possible to reduce its energy load by $21.8 \%$, wear of friction linings by $19.9 \%$, and increase the braking torque by $13.2 \%$.

Design and verification calculation of frictional units of tapeshoe brakes of drawworks: Standard (Baku: Apostrophe: 2015). 10. D.A. Volchenko, M.V. Kindrachuk, N.A. Volchenko, S.V. Nikipchuk, M.M. Nasirova, N.B. Klochko, A.O. Yurchuk, J. Nano- Electron. Phys. 12 No 6, 06020 (2020).

11. M. Chernets, M. Kindrachuk, A. Kornienko, A. Yurchuk, Acta Mechanica et Automatica 14 No 4, 206 (2020).

12. R.M. Tatsii, O.Y. Pazen, J. Eng. Phys. Thermophys. 89 No 2 , 357 (2016).

13. R.M. Tatsiy, O.Y. Pazen, S.Y. Vovk, L.Y. Ropyak, T.O. Pryhorovska, J. Serbian Soc. Comput. Mech. 13 No 2, 36 (2019).

14. L.Ya. Ropyak, M.V. Makoviichuk, Shatskyi, I.P. Prytula, L.O. Gryn, V.O. Belyakovskyi, Funct. Mater. 27 No 3, 638 (2020).

15. V. Marchuk, M. Kindrachuk, O. Tisov, A. Kornienko, O. Radko, V. Kharchenko, Funct. Mater. 26 No 4, 773 (2019).

16. A. Velychkovych, I Petryk, L. Ropyak, Shock Vib. 3292713 (2020).

17. I.P. Shatskii, V.V. Perepichka, J. Appl. Mech. Tech. Phys. 54 No 6, 1016 (2013).

18. A.S. Velichkovich, I.I. Popadyuk, V.M. Shopa, Chem. Petrol. Eng. 46 No 9-10, 518 (2011).

19. A.S. Velichkovich, I.I. Popadyuk, I.P. Shatskii, V.M. Shopa, Strength Mater. 23 No 3, 279 (1991). 
20. V.M. Shopa, I.P. Shatskii, I.I. Popadyuk, Soviet Eng. Res. 9 No 3, 42 (1989).

21. N. Malanchuk, R. Martynyak B. Monastyrskyy, Int. J. Solids Struct. 48 No 11-12, 1791 (2011).

22. V.S. Kolesov, N.M. Vlasov, L.O. Tisovskii, I.P. Shatskii, Int. Appl. Mech. 28 No 7, 426 (1992).

23. A. Yevtushenko, M. Kuciej, E. Och, Int. Commun. Heat Mass Transfer. 87, 288 (2017).

24. P.P. Krasnyuk, Strength Mater. 40 No 3, 381 (2008).

25. M. Chernets, Ju. Chernets, Proc. JMechE. Part J: Journal of Engineering Tribology 231 No 1, 57 (2017).

26. P.A. Vityaz', A.I. Komarov, V.I. Komarova, J. Frict. Wear. 29 No 5, 325 (2008).

27. N.V. Vasil'ev, A.Y. Varaksin, Y.A. Zeigarnik, K.A. Khodakov, A.V. Epel'fel'd, High Temp. 55 No 6, 880 (2017).

28. I.B. Ivasenko, V.M. Posuvailo, M.D. Klapkiv, V.A. Vynar, S.I. Ostap'yuk, Mater. Sci. 45 No 3, 460 (2009).

29. L.O. Snizhko, A. Yerokhin, N.L. Gurevina, D.O. Misnyankin, A.V. Ciba A. Matthews, Surf. Coat. Technol. 205 No 5, 1527 (2010).

30. V.M. Fedirko, I.M. Pohrelyuk, O.H. Luk'yanenko, S.M. Lavrys', M.V. Kindrachuk, O.I. Dukhota, O.V. Tisov, V.V. Zahrebel'nyi, Mater. Sci. 53 No 5, 691 (2018).

31. I.P. Shatskyi, L.Y. Ropyak, M.V. Makoviichuk, Strength Mater. 48 No 5, 726 (2016).

32. L.Ya. Ropyak, I,P. Shatskyi, M.V. Makoviichuk, Metallofiz. Nov. Tekhnol. 39 No 4, 517 (2017).
33. L. Ropyak, I. Schuliar, O. Bohachenko, Eastern-European Journal of Enterprise Technologies 1 No 5(79), 52 (2016).

34. M.V. Chernets, J. Kelbinski, R.Ja. Jarema, Mater. Sci. 47 No 1, 45 (2011).

35. V.B. Tarel'nyk, O.P. Gaponova, Y.V. Konoplyanchenko, M.Y Dovzhyk, Metallofiz. Nov. Tekhnol. 38 No 12, 1611 (2016).

36. M.I. Pashechko, V.V. Shyrokov, Z.A. Duryahina, Kh.B. Vasyliv, Mater. Sci. 39 No 1, 108 (2003)

37. V.B. Tarelnyk, O.P. Gaponova, I.V. Konoplianchenko, M.Ya. Dovzhyk, Metallofiz. Nov. Tekhnol. 39 No 3, 363 (2017).

38. I.P. Shatskyi, V.V. Perepichka, L.Ya. Ropyak, Metallofiz. Nov. Tekhnol. 42 No 1, 69 (2020).

39. N.A. Dolgov, I.V. Smirnov, A.V. Besov, Powder Metall. Metal Ceram. 54 No 1-2, 40 (2015).

40. V.S. Antonyuk, Y.Y. Bondarenko, S.O. Bilokin', V.O. Andrienko, M.O. Bondarenko, J. Nano- Electron. Phys. 11 No 6, 06024 (2019).

41. L. Ropyak, V. Ostapovych, Eastern European Journal of Enterprise Technologies 2 No 5, 50 (2016)

42. N.A. Volchenko, P.S. Krasin, D.A. Volchenko, A.V. Voznyi, IOP Conf. Series: Mater. Sci. Eng. 327 No 3, 032059 (2018).

43. N.A. Volchenko, D.A. Volchenko, P.A. Polyakov, E.S. Fedotov, A.S. Evchenko, IOP Conf. Series: Mater. Sci. Eng. $\mathbf{5 6 0}$ No 1, 012194 (2019).

44. A.Kh. Dzhanakhmedov, A.I. Volchenko, K.T. Nabizade Tribology: friction, wear, lubrication (Azerbaidzhan, Baku: ApostrofA: 2019).

45. A. Dykha, D. Marchenko, Int. J. Eng. Technol. 7 No 2, 4 (2018).

\section{Нанорідини в системах охолодження і їх ефективність}

Д.О. Вольченко ${ }^{1}$, М.В. Кіндрачук ${ }^{2}$, Б.В. Долішнийํㅜ В.С. Скрипник ${ }^{1}$, Д.І. Журавльов ${ }^{1}$, І.Б. Малик ${ }^{3}$, А.О. Юрчук ${ }^{2}$, О.І. Духота ${ }^{2}$

${ }^{1}$ Івано-Франківський національний технічний університет нафтии і газу, вул. Карпатська, 15, 76000 Івано-Франківськ, Украӥна

${ }^{2}$ Національний авіаційний університет, пр. Люболира Гузара, 1, о2000 Київ, Украӥна

3 Дрогобицький спеціалізований коледж нафьти і газу, вул. М. Грушевського, 57, 82100 Дрогобич, Украйна

У матеріалах статті показано, що на підставі багатофакторного аналізу запропоновані моделі нанорідин враховані в базових рідинах; зіткнення між наночастинками і молекулами; наночастинки, які обумовлені броунівським рухом; теплова дифузія наночастинок і їх взаємодія з молекулами; формування траекторій перколяції з низьким теплоемностним опором в рідини; вплив міжфазного і прикордонного шарів при розділі твердої і рідкої фаз; ефект поверхневих оболонок; тонкі наношари; кластеризація частинок. Дослідження нанорідин зводиться до визначення їх коефіціента теплопровідності. Встановлено, що отримані величини коефіціентів теплопровідності більше в 10-ки разів звичайних і тому вони не вписуються в класичні розрахункові схеми при визначенні коефіціентів теплопередачі. Для порожнин систем охолодження нанорідинами виявляеться, що термічні опори тепловіддачі і теплопровідності за величиною е фіктивними. Це викликано тим, що в порожнинах охолодження рушійною силою є скачки потеціалів між шарами нанорідин. Ми вибрали матеріали для створення нанорідин, які будуть використовуватися в гальмівній системі нової конструкції. Вона утворена частинками $\mathrm{Al}_{2} \mathrm{O}_{3}$, покритих полімерним матеріалом ФК-24А. Діаметр наночастинок становив 15,35 і 80 мкм. Збільшення розміру частинок і їх концентрації призводить до збільшення теплопровідності рідини. Замість контакту нанорідин і металевих компонентів змінюеться електричний потенціал і напруженість електричного поля нанорідин, що також описано тут. Коли температура нанорідини піднімаеться вище $100^{\circ} \mathrm{C}$, вона може стати електролітом. Використання нанорідин для змащення гальмівної системи лебідки знижуе знос фрикційних вузлів на $\sim 20$ \% і збільшуе гальмівний момент приблизно на $13 \%$.

Ключові слова: Двигун внутрішнього згоряння, Пристрій гальмування, Нанорідина, Наночастинки в полімерній оболонці, Потенціали: температурний, електричний та хімічний. 